\title{
PENGONTROLAN POSISI SOLAR CELL OTOMATIS DENGAN MENGGUNAKAN SENSOR CAHAYA LIGHT DEPENDENT RESISTOR UNTUK ENERGI ALTERNATIF
}

\author{
Ivany Sarief \\ Jurusan Teknik Elektro, Fakultas Teknik, Universitas Sangga Buana, Bandung \\ ivany.sarief@usbypkp.ac.id
}

\begin{abstract}
ABSTRAK
Seperti yang sudah kita semua ketahui bahwa penggunaan bahan bakar konvensional seperti minyak dan batubara pada hampir semua sektor kehidupan terutama sektor kebutuhan energi listrik jelas menyebabkan semakin menipisnya persediaan sumber daya alam di Indonesia, dengan permasalahan yang kita hadapi saat ini mendorong upaya-upaya pengembangan energi alternatif terbarukan. Salah satu energi terbarukan yang mempunyai potensi sangat besar di kehidupan kita khusunya di Indonesia yang berada di wilayah tropis adalah energi matahari. Dari gambaran masalah diatas, penulis ingin mencoba memanfaatkan sumber energi matahari yang kemudian di konversi menjadi energi listrik dengan menggunakan sebuah alat yaitu Solar Cell dengan menambahkan alat sensor cahaya matahari untuk lebih mengoptimalkan daya serap alat tersebut. Solar Cell adalah pengubah energi matahari menjadi tenaga listrik. Posisi matahari yang selalu berubah terhadap permukaan bumi mengakibatkan solar cell hanya akan bekerja optimal pada siang hari saja. Untuk mengoptimalkan kinerja solar cell sepanjang siang hari adalah dengan mengatur posisi permukaan solar cell selalu tegak lurus terhadap arah datangnya matahari. Kontrol posisi otomatis solar cell mempu meningkatkan kinerja solar cell dari posisi statis sebesar 1,73 Volt dc menjadi rata-rata sebesar 1,92 Volt dc pada posisi dinamis. Nilai arus solar cell statis adalah sebesar 1,09 Ampere, sedangkan pada posisi dinamis dengan menerapkan kontrol posisi mendapatkan arus rata-rata 1,29 Ampere. Daya rata-rata daya solar cell statis adalah sebesar 0,17 Watt, sedangkan pada posisi dinamis dengan menerapkan kontrol posisi mendapatkan daya ratarata sebesar 0,23 Watt. Efisiensi daya dengan pengontrolan posisi solar cell otomatis adalah sebesar rata-rata $32,44 \%$.
\end{abstract}

Kata Kunci: solar cell; sensor cahaya; kontrol posisi; posisi statis; posisi dinamis

\section{PENDAHULUAN}

Sumber penghasil energi listrik semakin lama akan semakin menipis, sehingga kelangsungan untuk distribusi listrik akan terhambat, dan semakin meningkatnya biaya yang diperlukan untuk menghasilkan energi listrik. Untuk mengatasi kesulitan itu, perlu dicari sumber alternatif penghasil energi listrik. Sumber penghasil energi listrik alternatif ini adalah dengan menggunakan cahaya matahari. Alat yang dapat mengkonversikan cahaya matahari menjadi energi listrik adalah solar cell atau kita biasa menyebutnya panel surya.

Solar Cell dapat menghantarkan daya maksimalnya jika posisi solar cell tegak lurus dengan arah datangnya sinar matahari. Sehingga untuk mengoptimalkan daya yang dihasilkan oleh solar cell, maka perlu dirancang alat yang memposisikan agar solar cell selalu berada pada posisi tegak lurus terhadap arah datangnya sinar matahari. Untuk mengatasi permasalahan posisi sollar cell ini, maka perlu dirancang menggunakan motor penggerak posisi solar cell agar solar cell dapat selalu berada pada posisi tegak lurus terhadap arah datangnya sinar matahari. Motor ini berfungsi untuk mengikuti sinar matahari dari terbit sampai tenggelam.

Alat ini didesain otomatis untuk mengikuti pergerakan matahari menggunakan sensor LDR, sehigga kontroller akan mengatur pergerakan motor sampai nilai resistansi yang ada pada setiap LDR seimbang, sehingga solar cell akan berada pada posisi yang diinginkan. Dengan dibuatnya modul kontrol posisi solar cell ini di harapkan energi yang di terima oleh solar cell akan lebih maksimal bila di bandingkan 
dengan posisi solar cell yang statis menghadap ke atas.

Seiring dengan berkembangnya pemikiran manusia akan energi alternatif solar cell untuk masyarakat kalangan menengah kebawah terutama mereka yang memiliki pekerjaan sebagai pedagang kakilima yang sering kali harus mengeluarkan uang lebih untuk membayar sewa listrik dan terkadang menggunakan lilin untuk penerangan ketika berdagang di malam hari. Selain itu solar cell juga ramah lingkungan dan juga tidak membutuhkan perawatan yang mahal. Solar cell juga cocok digunakan di wilayah Indonesia yang memiliki iklim tropis dan memiliki suhu panas yang cukup untuk penggunaan solar cell. Alat ini nanti nya akan dapat membantu para pedagang kaki lima untuk memenuhi kebutuhan energi listrik sekaligus mengurangi pengeluaran berlebih dalam penjualan.

\section{TINJAUAN PUSTAKA}

\subsection{Solar Cell}

Solar cell atau biasa disebut juga panel surya adalah alat yang terdiri dari sel surya yang mengubah cahaya menjadi listrik. Mereka disebut surya atau matahari atau "sol" karena matahari merupakan sumber cahaya terkuat yang dapat dimanfaatkan. Solar cell sering kali disebut sel photovoltaic, photovoltaic dapat diartikan sebagai "cahaya listrik". Sel surya bergantung pada efek photovoltaic untuk menyerap energi.

Pada umumnya, Solar cell merupakan sebuah hamparan semi konduktor yang dapat menyerap photon dari sinar matahari dan mengubahnya menjadi listrik. Sel surya tersebut dari potongan silikon yang sangat kecil dengan dilapisi bahan kimia khusus untuk membentuk dasar dari sel surya. Sel surya pada umumnya memiliki ketebalan minimum $0.3 \mathrm{~mm}$ yang terbuat dari irisan bahan semikonduktor dengan kutub positif dan negatif. Pada sel surya terdapat sambungan (function) antara dua lapisan tipis yang terbuat dari bahan semikonduktor yang masing-masing diketahui sebagai semikonduktor jenis "P" (positif) dan semikonduktor jenis "N" (negatif). Silikon jenis P merupakan lapisan permukaan yang dibuat sangat tipis supaya cahaya matahari dapat menembus langsung mencapai function. Bagian $\mathrm{P}$ ini diberi lapisan diberi lapisan nikel yang berbentuk cincin, sebagai terminal keluaran positif. Dibawah bagian $\mathrm{P}$ terdapat berbagai jenis $\mathrm{N}$ yang dilapisi dengan nikel juga sebagai terminal keluaran negatif. (digilib.its.ac/public/ITS-Master13287-Chapter1I.pdf).

\section{II.1. Proses Konversi Solar Cell}

Proses pengubahan atau konversi cahaya matahari menjadi listrik ini dimungkinkan karena bahan material yang menyusun sel surya berupa semikonduktor, lebih tepatnya tersusun atas dua jenis semikonduktor, yaitu jenis $\mathrm{n}$ dan jenis $\mathrm{p}$. Semikonduktor jenis $\mathrm{n}$ merupakan semikonduktor yang memiliki kelebihan elektron, sehingga kelebihan muatan negatif, $(\mathrm{n}=$ negatif $)$. Sedangkan semikonduktor jenis $\mathrm{p}$ memiliki kelebihan hole, sehingga kelebihan muatan positif, $(\mathrm{p}=$ positif).

Pada awalnya, pembuatan dua jenis semikonduktor ini dimaksudkan untuk meningkatkan tingkat konduktifitas atau tingkat kemampuan daya hantar listrik dan panas semikonduktor alami. Di dalam semikonduktor alami ini, elektron maupun hole memiliki jumlah yang sama. Kelebihan elektron atau hole dapat meningkatkan daya hantar panas atau listrik dari sebuah semikonduktor. Dua jenis semikonduktor $n$ dan $\mathrm{p}$ ini jika disatukan akan membentuk sambungan $\mathrm{p}-\mathrm{n}$ atau dioda $\mathrm{p}-\mathrm{n}$. Istilah lain menyebutnya dengan sambungan metalurgi (metallurgical junction).

\subsection{Jenis Solar Cell}

Ada beberapa jenis panel surya yang dijual dipasaran:

1. Jenis pertama, yaitu jenis yang terbaik dan yang terbanyak digunakan masyarakat saat ini, adalah jenis monokristalin. Panel ini memiliki tingkat efisiensi antara 12 sampai $14 \%$.

2. Jenis kedua adalah jenis polikristalin atau multi kristalin, yang terbuat dari kristal silikon dengan tingkat efisiensi antara 10 sampai $12 \%$.

3. Jenis ketiga adalah silikon jenis amorphous, yang berbentuk film tipis.

4. Jenis keempat adalah panel surya yang terbuat dari GaAs (Gallium Arsenide) yang lebih efisien pada temperatur tinggi. 


\subsection{Sensor Cahaya LDR}

LDR (Light Dependent Resistor) merupakan salah satu komponen resistor yang nilai resistansinya akan berubah-ubah sesuai dengan intensitas cahaya yang mengenai sensor ini. LDR juga dapat digunakan sebagai sensor cahaya. Perlu diketahui bahwa nilai resistansi dari sensor ini sangat bergantung pada intensitas cahaya. Semakin banyak cahaya yang mengenainya, maka akan semakin menurun nilai resistansinya. Sebaliknya jika semakin sedikit cahaya yang mengenai sensor (gelap), maka nilai hambatannya akan menjadi semakin besar sehingga arus listrik yang mengalir akan terhambat.

Umumnya Sensor LDR memiliki nilai hambatan 200 Kilo Ohm pada saat dalam kondisi sedikit cahaya (gelap), dan akan menurun menjadi 500 Ohm pada kondisi terkena banyak cahaya. Tak heran jika komponen elektronika peka cahaya ini banyak diimplementasikan sebagai sensor lampu penerang jalan, lampu kamar tidur, alarm dan lain-lain.

\subsection{Fungsi Sensor LDR}

LDR berfungsi sebagai sebuah sensor cahaya dalam berbagai macam rangkaian elektronika seperti saklar otomatis berdasarkan cahaya yang jika sensor terkena cahaya maka arus listrik akan mengalir (ON) dan sebaliknya jika sensor dalam kondisi minim cahaya (gelap) maka aliran listrik akan terhambat (OFF). LDR juga sering digunakan sebagai sensor lampu penerang jalan otomatis, lampu kamar tidur, alarm, rangkaian anti maling otomatis menggunakan laser, suter kamera otomatis, dan masih banyak lagi yang lainnya.

\subsection{Cara Kerja Sensor LDR}

Prinsip kerja LDR sangat sederhana tak jauh berbeda dengan variable resistor pada umumnya. LDR dipasang pada berbagai macam rangkaian elektronika dan dapat memutus dan menyambungkan aliran listrik berdasarkan cahaya. Semakin banyak cahaya yang mengenai LDR maka nilai resistansinya akan menurun, dan sebaliknya semakin sedikit cahaya yang mengenai LDR maka nilai hambatannya akan semakin membesar.

\subsection{Motor Servo}

Motor servo merupakan salah satu jenis motor DC yang sering diaplikasikan dalam bidang robotik. Biasanya motor servo digunakan untuk penggerak lengan atau persendian robot karena memiliki kemampuan dapat berputar searah jarum jam dan berlawanan arah jarum jam. Motor servo adalah jenis motor DC dengan sistem umpan balik tertutup yang terdiri dari sebuah motor DC, serangkaian gear, rangkaian kontrol, dan juga potensiometer. Jadi motor servo sebenarnya tak berdiri sendiri, melainkan didukung oleh komponen-komponen lain yang berada dalam satu paket.

\subsection{Prinsip Kerja Motor Servo}

Motor servo dikendalikan dengan memberikan sinyal modulasi lebar pulsa (Pulse Wide Modulation / PWM) melalui kabel kontrol. Lebar pulsa sinyal kontrol yang diberikan akan menentukan posisi sudut putaran dari poros motor servo. Sebagai contoh, lebar pulsa dengan waktu $1,5 \mathrm{~ms}$ (mili detik) akan memutar poros motor servo ke posisi sudut $90^{\circ}$. Bila pulsa lebih pendek dari 1,5 ms maka akan berputar ke arah posisi $0^{0}$ atau ke kiri (berlawanan dengan arah jarum jam), sedangkan bila pulsa yang diberikan lebih lama dari 1,5 ms maka poros motor servo akan berputar ke arah posisi $180^{\circ}$ atau ke kanan (searah jarum jam).

Ketika lebar pulsa kendali telah diberikan, maka poros motor servo akan bergerak atau berputar ke posisi yang telah diperintahkan, dan berhenti pada posisi tersebut dan akan tetap bertahan pada posisi tersebut. Jika ada kekuatan eksternal yang mencoba memutar atau mengubah posisi tersebut, maka motor servo akan mencoba menahan atau melawan dengan besarnya kekuatan torsi yang dimilikinya (rating torsi servo). Namun motor servo tidak akan mempertahankan posisinya untuk selamanya, sinyal lebar pulsa kendali harus diulang setiap 20 ms (mili detik) untuk menginstruksikan agar posisi poros motor servo tetap bertahan pada posisinya.

\subsection{Arduino}

Arduino adalah pengendali mikro singleboard yang bersifat open-source, diturunkan dari wiring platform, dirancang untuk memudahkan penggunaan elektronik dalam 
berbagai bidang. Hardwarenya memiliki prosesor Atmel AVR dan softwarenya memiliki bahasa pemrograman sendiri. Saat ini Arduino sangat populer di seluruh dunia. Banyak pemula yang belajar mengenal robotika dan elektronika lewat Arduino karena mudah dipelajari. Tapi tidak hanya pemula, para hobbyist atau profesional pun ikut senang mengembangkan aplikasi elektronik menggunakan Arduino. Bahasa yang dipakai dalam Arduino bukan.assembler yang relatif sulit, tetapi bahasa $\mathrm{C}$ yang disederhanakan dengan bantuan pustaka-pustaka (libraries) Arduino.

\section{HASIL DAN PEMBAHASAN}

\subsection{Hasil Pengambilan Data}

Pada penelitian ini dilakukan dua jenis pengambilan data yaitu yang pertama adalah membandingkan hasil solar cell dalam keadaan statis dan dinamis kemudian yang kedua adalah menguji seberapa lama batere yang telah diisi oleh solar cell dapat bertahan apabila diberikan beban satu buah lampu LED.

Pada pengambilan data solar cell dalam keadaan statis dan dinamis akan diperoleh data tegangan dan kuat arus yang kemudian dapat diperoleh juga daya yang dihasilkan oleh solar cell tersebut. Sedangkan pada pengambilan data yang kedua akan diperoleh data berapa lama baterai sanggup menyalakan sebuah lampu (dalam satuan jam).

\subsection{Perbandingan Hasil Solar Cell Yang Statis dan Dinamis}

Pada solar cell statis maupun dinamis dilakukan pengambilan data yaitu berupa data tegangan (V), kuat arus (i) secara langsung dari multimeter, kemudian daya $(\mathrm{P})$ yang di hasilkan oleh solar cell statis dan dinamis dapat diketahui melalui proses perkalian antara tegangan (V) terhadap kuat arus (i). Pengambilan data dilakukan selama 10 jam dari pukul $07.00-17.00$.

\subsection{Tegangan}

Tegangan (V) yang dihasilkan oleh solar cell statis dan dinamis setelah dilakukan pengambilan data dari jam 07.00-17.00 sebanyak 11 kali kemudian diambil rata-rata dan juga perbedaan efisiensi nya.

Tegangan yang dihasilkan solar cell baik pada posisi statis maupun dinamis cenderung meningkat pada jam $07.00-12.00$ namun kemudian cenderung menurun kembali pada jam 12.00 - 17.00, ini kemungkinan terjadi di karenakan cahaya matahari pada jam 07.00 12.00 semakin lama semakin terik yang berimbas pada meningkatnya tegangan yang dihasilkan oleh solar cell sedangkan pada jam 12.00 - 17.00 cahaya matahari cenderung meredup dan mengakibatkan tegangan yang dihasilkan pun menurun.

Tabel 1 Hasil Tegangan Solar Cell Statis dan Dinamis

\begin{tabular}{|c|c|c|c|}
\hline \multirow{2}{*}{ No. } & \multirow{2}{*}{$\begin{array}{l}\text { Waktu } \\
\text { (WIB) }\end{array}$} & \multicolumn{2}{|c|}{ Tegangan (volt) } \\
\hline & & Statis & Dinamis \\
\hline 1. & 07.00 & 1.60 & 1.76 \\
\hline 2. & 08.00 & 1.68 & 1.76 \\
\hline 3. & 09.00 & 1.73 & 1.78 \\
\hline 4. & 10.00 & 1.75 & 2.16 \\
\hline 5. & 11.00 & 1.76 & 2.22 \\
\hline 6. & 12.00 & 2.21 & 2.25 \\
\hline 7. & 13.00 & 1.81 & 2.05 \\
\hline 8. & 14.00 & 1.75 & 1.85 \\
\hline 9. & 15.00 & 1.75 & 1.82 \\
\hline 10. & 16.00 & 1.53 & 1.82 \\
\hline 11. & 17.00 & 1.51 & 1.62 \\
\hline & naah & 19.08 & 21.09 \\
\hline & -rata & 1.73 & 1.92 \\
\hline & gkatan & & \\
\hline
\end{tabular}

Dari tabel dan grafik di atas terlihat tegangan yang dihasilkan solar cell baik secara statis dan dinamis selalu di bawah 3 volt dikarenakan tegangan maksimum yang bisa di hasilkan solar cell tersebut hanya 6volt dan pada saat pengambilan data dilakukan kondisi sinar matahari tidak terlalu terik karena beberapa kali sedikit tertutup awan. 


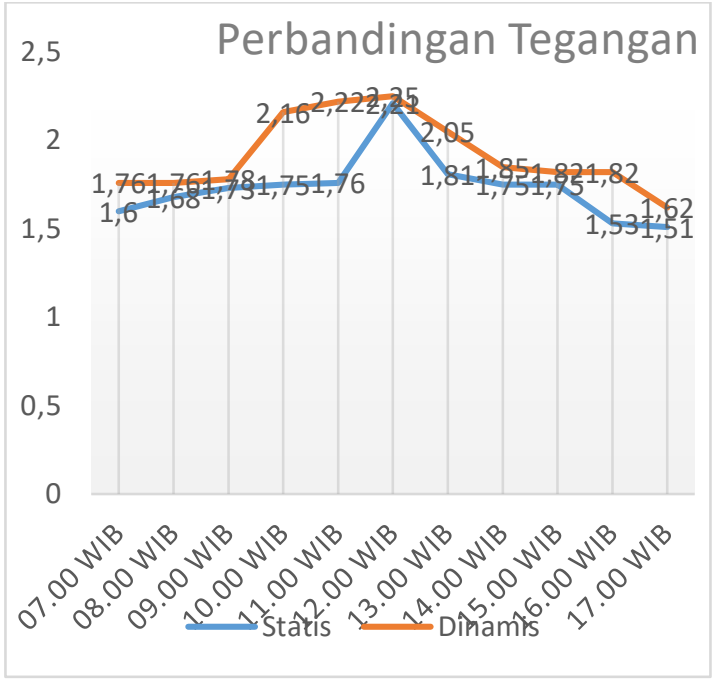

Grafik 1 Grafik Perbandingan Hasil

Tegangan Solar Cell Statis dan Dinamis

Dari tabel dan grafik di atas juga bisa terlihat bahwa tegangan solar cell yang dihasilkan pada posisi dinamis selalu lebih besar dari tegangan solar cell yang dihasilkan pada posisi statis. Tegangan solar cell yang di hasilkan pada posisi dinamis mengalami peningkatan sebesar $10.53 \%$ dari tegangan yang dihasilkan solar cell pada posisi statis.

\subsection{Kuat Arus}

Tabel 2 Hasil Kuat Arus Solar Cell Statis dan Dinamis

\begin{tabular}{|c|c|c|c|}
\hline \multirow{2}{*}{ No. } & \multirow{2}{*}{$\begin{array}{l}\text { Waktu } \\
\text { (WIB) }\end{array}$} & \multicolumn{2}{|c|}{ Kuat Arus (A) } \\
\hline & & Statis & Dinamis \\
\hline 1. & 07.00 & 0.080 & 0.10 \\
\hline 2. & 08.00 & 0.093 & 0.10 \\
\hline 3. & 09.00 & 0.096 & 0.12 \\
\hline 4. & 10.00 & 0.10 & 0.13 \\
\hline 5. & 11.00 & 0.12 & 0.15 \\
\hline 6. & 12.00 & 0.15 & 0.17 \\
\hline 7. & 13.00 & 0.10 & 0.13 \\
\hline 8. & 14.00 & 0.10 & 0.11 \\
\hline 9. & 15.00 & 0.10 & 0.10 \\
\hline 10. & 16.00 & 0.075 & 0.10 \\
\hline 11. & 17.00 & 0.073 & 0.080 \\
\hline \multicolumn{2}{|c|}{ Jumlah } & 1.09 & 1.29 \\
\hline \multicolumn{2}{|c|}{ Rata-rata } & 0.09 & 0.11 \\
\hline \multicolumn{2}{|c|}{ Peningkatan } & \multicolumn{2}{|c|}{$18.35 \%$} \\
\hline
\end{tabular}

Kuat arus (A) yang dihasilkan oleh solar cell statis dan dinamis setelah dilakukan pengambilan data dari jam 07.00-17.00 sebanyak 11 kali kemudian diambil rata-rata dan juga perbedaan efisiensi nya.

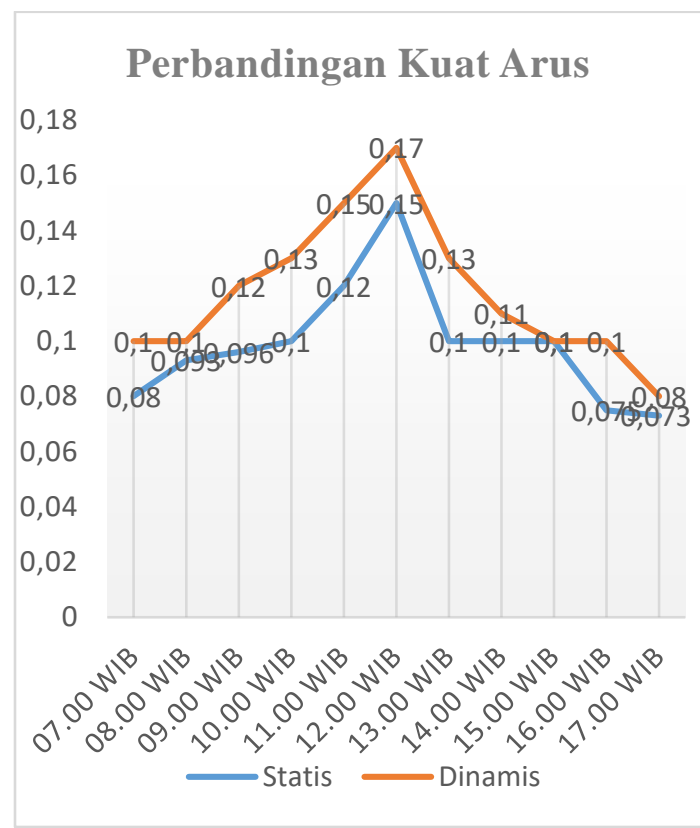

Grafik 2 Grafik Perbandingan Hasil Kuat Arus Solar Cell Statis dan Dinamis

Kuat arus yang dihasilkan solar cell baik pada posisi statis maupun dinamis cenderung meningkat pada jam $07.00-12.00$ namun kemudian cenderung menurun kembali pada jam 12.00 - 17.00, ini kemungkinan terjadi dikarenakan cahaya matahari pada jam 07.00 - 12.00 semakin lama semakin terik yang berimbas pada meningkatnya kuat arus yang dihasilkan oleh solar cell sedangkan pada jam 12.00 - 17.00 cahaya matahari cenderung meredup dan mengakibatkan kuat arus yang dihasilkan pun menurun.

Dari tabel dan grafik di atas juga bisa terlihat bahwa kuat arus solar cell yang dihasilkan pada posisi dinamis selalu lebih besar dari kuat arus solar cell yang dihasilkan pada posisi statis. Kuat arus solar cell yang dihasilkan pada posisi dinamis mengalami peningkatan sebesar $18.35 \%$ dari kuat arus yang dihasilkan solar cell pada posisi statis.

\subsection{Daya}

Daya (Watt) yang dihasilkan oleh solar cell dinamis di dapat dari hasil perkalian tegangan dan kuat arus.

Daya yang dihasilkan solar cell baik pada posisi statis maupun dinamis cenderung 
meningkat pada jam $07.00-12.00$ namun kemudian cenderung menurun kembali pada jam $12.00-17.00$, ini terjadi karena tegangan dan kuat arus yang dihasilkan solar cell pun selalu meningkat pada jam 07.00 12.00 dan kembali menurun pada jam 12.00 -17.00 .

\subsection{Hasil Pengambilan Data Kedua}

Hasil pengambilan data yang kedua di dapat ketika dilakukan percobaan dengan menghubungkan konektor bola lampu ke power bank.

Pada pengambilan data kedua di dapatkan hasil daya yang tersimpan pada power bank setelah dilakukan pengisian selama 10 jam oleh solar cell dalam keadaan dinamis dan di berikan beban satu buah bola lampu dengan konsumsi daya 5watt dapat bertahan selama 4 jam lebih. Hasil ini di dapat dari percobaan ketika power bank mulai diberikan beban pada pukul 18.00 dan habis pada pukul 22.15 yang di tandai dengan meredup nya bola lampu.

\subsection{Pembahasan}

Dari kedua pengambilan data yang telah dilakukan dan melihat hasilnya bisa disimpulkan bahwa penelitian ini berjalan dengan baik karena alat yang dibuat bekerja sesuai dengan apa yang di harapkan, Selain itu daya yang tersimpan pada power bank juga cukup untuk bisa menyalakan satu buah bola lampu yang menjadi tujuan dari penelitian ini.

\section{KESIMPULAN}

Dari pembahasan yang sudah dijelaskan pada bab-bab sebelumnya dapat ditarik kesimpulan bahwa tujuan dari penelitian ini sudah tercapai, yaitu merancang sebuah alat untuk mengontol posisi solar cell agar sesalu tegak lurus terhadap sinar matahari yang ada. Dari pengambilan data yang sudah dilakukan didapat adanya peningkatan tegangan sebesar $10.53 \%$, peningkatan kuat arus sebesar $18.35 \%$ dan peningkatan daya sebesar $32.44 \%$.

Perancangan alat ini juga bisa di jadikan sebagai sumber energi alternatif karena bisa di gunakan untuk berjualan di malam hari dan mengurangi biaya pengeluaran pedagang.

\section{DAFTAR PUSTAKA}

[1] Adhi Wibowo, Rachmat. 2008. Melihat prinsip kerja sel surya lebih dekat.

[2] Emzir. 2009. Metodologi Penelitian Pendidikan, Kuantitatif dan Kualitatif. Jakarta: Raja Grafindo Persada.

[3] Janis panel surya di http://imall.iteadstudio.com. (diakses tanggal 15 April 2019)

[4] Santoso, Hari. 2015. Panduan praktis arduino untuk pemula. Jakarta: Elang Sakti.

[5] Supranto. 2015. Teknologi Tenaga Surya. Yogyakarta: Global Pustaka Utama.

[6] Tarif dasar listrik PLN 2019 dan Cek Tagihan Listrik Online di http://www.obengplus.com/articles/4518/1/ (di akses 30 Agustus 2019). 